CZASOPISMO INŻYNIERII LADDOWEJ, ŚRODOWISKA I ARCHITEKTURY JOURNAL OF CIVIL ENGINEERING, ENVIRONMENT AND ARCHITECTURE JCEEA, t. XXXII, z. 62 (3/II/15), lipiec-wrzesień 2015, s. 351-362

\author{
Alicja PUSZKAREWICZ ${ }^{1}$ \\ Jadwiga KALETA ${ }^{2}$ \\ Dorota PAPCIAK ${ }^{3}$
}

\title{
USUWANIE FENOLU W PROCESIE ADSORPCJI
}

\begin{abstract}
Do usuwania związków fenolu z roztworów wodnych zastosowany został naturalny adsorbent mineralny (surowy attapulgit - Abso'Net Superior Special (ASS)). Właściwości adsorpcyjne attapulgitu zostały określone metodą statyczną i dynamiczną. Badania przeprowadzono na modelowym roztworze fenolu o stężeniu początkowym $\mathrm{C}_{0}=20 \mathrm{mg} \cdot \mathrm{dm}^{-3}$, w temperaturze $20^{\circ} \mathrm{C}$. Dla testowanego minerału proces adsorpcji dobrze opisywały izotermy adsorpcji Froundlicha. W badaniach stwierdzono, że adsorpcja fenolu nieco lepiej zachodziła przy odczynie obojętnym i kwaśnym. Na podstawie badań zaobserwowano, że czas adsorpcji miał istotny wpływ na skuteczność usuwania fenolu, a równowaga adsorpcyjna nastąpiła po 180 minut. W warunkach przepływowych najefektywniej pracowało złoże $\mathrm{z}$ najdłuższym czasem retencji $\mathrm{tr}=10$ minut. Związki fenolu w początkowej fazie pracy kolumny usuwane były do wartości poniżej $0,5 \mathrm{mg} \cdot \mathrm{dm}^{-3}$. W punkcie wyczerpania złoża uzyskano pojemność adsorpcyjną $\mathrm{P}=2,45 \mathrm{mg} \cdot \mathrm{g}^{-1}$. Usuwanie fenolu w procesie filtracji na złożu $\mathrm{z}$ attapulgitu okazało się skuteczne. Badania wykazały, że adsorbent, o granulacji 0,6 - 1,3 mm zastosowany jako złoże adsorpcyjne mógłby stanowić alternatywę dla skutecznego podczyszczania roztworów zawierających fenol o stężeniach nie przekraczających $20 \mathrm{~g} \cdot \mathrm{m}^{-3}$.
\end{abstract}

Słowa kluczowe: fenol, adsorpcja, filtracja, attapulgit

\section{Wprowadzenie}

Fenole są związkami organicznymi, posiadającymi grupy karboksylowe połączone $\mathrm{z}$ atomami węgla $\mathrm{w}$ pierścieniu aromatycznym. Są to związki odznaczające się dużą aktywnością chemiczną i łatwym utlenianiem się, a także słabą rozpuszczalnością w wodzie, przez co stanowią duże zagrożenie dla środowiska wodnego [4].

\footnotetext{
${ }^{1}$ Corresponding Author: Alicja Puszkarewicz, Politechnika Rzeszowska, al. Powstańców Warszawy 12, 35-959 Rzeszów, apuszkar@prz.edu.pl, tel. 178651720

2 Jadwiga Kaleta, Politechnika Rzeszowska, al. Powstańców Warszawy 12, 35-959 Rzeszów, jkaleta@prz.edu.pl, tel.178651301

3 Dorota Papciak, Politechnika Rzeszowska, al. Powstańców Warszawy 12, 35-959 Rzeszów, dpapciak@prz.edu.pl, tel.178651301
} 
Fenol i jego pochodne są reagentami stosowanymi często w różnych gałęziach przemysłu, Do powszechnie znanych pochodnych fenolu należą m.in.: pirogalol, 2,4 - dichlorofenol, 2,4,5 - trichlorofenol, $\alpha$ i $\beta$ - naftol oraz wiele innych $[5,20]$. Należą do produktów pośrednich w przemysłowej syntezie różnorodnych substancji i są zaliczane do bardzo ważnych i często stosowanych związków w przemyśle chemicznym $[6,9,10]$.

Fenole są szkodliwe dla ryb już w ilościach od kilku do kilkunastu $\mathrm{mg} / \mathrm{dm}^{3}$, zaś hydrochinon (pochodna fenolu) jest toksyczny w dawkach $0,2-0,5 \mathrm{mg} \cdot \mathrm{dm}^{-3}$. Mają one zdolność do kumulowania się w mięsie ryb, nadając mu nieprzyjemny smak i zapach. Bardzo wrażliwe na fenole są procesy samooczyszczania zachodzące w rzekach. Fenole zawarte w ściekach mogą również zakłócać procesy ich biologicznego oczyszczania. Szkodliwe stężenie fenolu w tym przypadku jest powyżej $5 \mathrm{mg} \cdot \mathrm{dm}^{-3}[2]$.

W ilościach normalnie spotykanych (ok. $0.005 \mathrm{mg} \cdot \mathrm{dm}^{-3}$ ) w wodach naturalnych nie są one szkodliwe dla zdrowia, mimo to woda taka poddawana chlorowaniu podczas dezynfekcji ma odrażający smak i zapach na skutek tworzenia się związków chloropochodnych [15]. Na podstawie wielu badań opublikowano szereg prac, w których stwierdzono, że adsorpcja na węglach aktywnych i wielu innych adsorbentach w formie granulowanej, włóknistej lub pylistej jest najlepszą i najbardziej skuteczną metodą oczyszczania wody z fenoli $[1,7,12,13,16$, $19,21]$.

Skuteczność przebiegu procesu adsorpcji zależy od takich parametrów jak: rodzaj oraz stężenie adsorbatów, odczyn $\mathrm{pH}$ roztworu adsorptywu, temperatura, czas procesu sorpcji, rodzaj stosowanego sorbentu, jego struktury porowatej, uziarnienia, powierzchni właściwej, gęstości, a także takich czynników jak: szybkość mieszania, prędkość filtracji, i innych. Usuwanie fenoli w procesie adsorpcji jest jednym $\mathrm{z}$ ostatnich elementów ciągu technologicznego uzdatniania wody $[11,14,20]$.

Niekorzystny wpływ fenoli na ekosystem wodny zmusza do podejmowania działań mających na celu ochronę zasobów wód naturalnych i efektywne eliminowanie ich ze ścieków i z wody przeznaczonej do zaopatrzenia odbiorców wody.

W pracy podjęto próbę określenia skuteczności usuwania fenolu z roztworów wodnych przy użyciu adsorbentu mineralnego Abso'Net Superior Special.

\section{Metodyka badań}

\section{Materiaty i przedmiot badań}

Badania prowadzono na modelowym roztworze wodnym. Sporządzono go na bazie wody destylowanej, do której dodawano związki fenolu. Stężenie fenolu w wodzie wynosiło $\mathrm{C}_{0}=20 \mathrm{mg} \cdot \mathrm{dm}^{-3}$. 
W badaniach laboratoryjnych jako materiał adsorpcyjny zastosowano granulat mineralny Abso'Net Superior Special (ASS). Uziarnienie adsorbentu wynosiło: od 0,6 - 1,3 mm.

Dane techniczne adsorbentu przedstawiono w tabeli 1.

Tab. 1. Dane techniczne adsorbentu Abso'Net Superior Special (ASS) [kata katologowa- Horpol]

Tab. 1. Technical Specifications of adsorbent Abso'Net Superior Special (ASS) [catalog card Horpol]

\begin{tabular}{|c|c|}
\hline Wygląd & Drobny granulat w kolorze kremowym \\
\hline Surowiec & Attapulgit wapienny \\
\hline $\begin{array}{c}\text { Gęstość nasypowa } \\
{\left[\mathbf{g}_{\left.\mathbf{d} \mathbf{d m}^{-3}\right]}\right.}\end{array}$ & 500 \\
\hline $\mathbf{p H}$ & $9 \pm 0,5$ \\
\hline Wilgotność $[\%]$ & $2,7 \pm 1$ \\
\hline
\end{tabular}

Attapulgit jest to glinokrzemian włóknisty (ang. filbrillar silicate) o wzorze chemicznym $\mathrm{Mg}_{5}[\mathrm{Al}] \mathrm{Si}_{8} \mathrm{O}_{20}\left(\mathrm{OH}_{2}\right)_{4}$, wykazujący sie dość dużą pojemnością sorpcyjną oscylującą $\mathrm{w}$ przedziale $0,15-0,30 \mathrm{mval} \cdot \mathrm{g}^{-1}$. Podobnie jak zeolity charakteryzuję się cechami sita molekularnego [18].

\section{Charakterystyka materiału adsorpcyjnego Abso'Net Superior Special (ASS):}

- wytwarzany z drobno zmielonego minerału o nazwie attapulgit, podczas procesu aktywacji

- w wysokiej temperaturze,

- jest to produkt naturalny (nie zawiera dodatków chemicznych, nie jest modyfikowany),

- jest produktem o bardzo niskiej emisji pyłów,

- jest ognioodporny,

- nie jest szkodliwy dla ludzi i zwierząt,

- jest odporny na ścieranie przy poddaniu działaniu mechanicznemu,

- po wchłonięciu płynu nie ulega rozkładowi,

- charakteryzuje się doskonałymi właściwościami adsorpcyjnymi oraz mechanicznymi,

- ma dobrą skuteczność przy wchłanianiu kwasów, w tym silnych,

- jest przeznaczony do usuwania wszelkiego typu wycieków, od płynów przemysłowych, zawiesin wodnych, przez węglowodory ( ropa, benzyna, oleje), rozpuszczalniki organiczne, do kwasów i związków zasadowych,

- posiada atest PZH. 
Proces adsorpcji przeprowadzono $\mathrm{z}$ zastosowaniem adsorbentu wyszlamowanego i wysuszonego w temperaturze $105^{\circ} \mathrm{C}$. Zawartość fenolu oznaczono metodą pośrednią polegającą na określaniu zawartości węgla organicznego przy pomocy laboratoryjnego analizatora TOC Sievers InnovOx firmy GE Analytical Instruments. Sporządzono krzywą wzorcową (przebieg liniowy) dla zakresu stężeń fenolu stosowanych w pracy $\left(1-50 \mathrm{mg} \cdot \mathrm{dm}^{-3}\right)$. Przed oznaczeniem każda próbka była przesączona przez sączek. Każda seria zawierała kolby dodatkowe stanowiące próby ślepe (bez adsorbentu lub adsorbatu).

Badania laboratoryjne zostały przeprowadzone w dwóch etapach:

- I etap - adsorpcja fenolu w warunkach statycznych (nieprzepływowych) - wpływ pH, kinetyka i izotermy adsorpcji Freundlicha i Langmuira,

- II etap - adsorpcja fenolu w warunkach dynamicznych (przepływowych).

Wphyw czasu kontaktu na proces adsorpcji w warunkach statycznych (kinetyka adsorpcji)

Wpływ czasu kontaktu na proces adsorpcji wyznaczano przy dawce sorbentu wynoszącej $10 \mathrm{~g} \cdot \mathrm{dm}^{-3}$. Do pięciu kolb stożkowych zawierających po $250 \mathrm{ml}$ wsypano odważki po $2,5 \mathrm{~g}$ adsorbentu. Następnie każdą z kolb wstrząsano kolejno przez $10 ; 30 ; 60 ; 120 ; 180,240,300,360$ minut i pozostawiono do 24 godzinach. sedymentacji. Po tym czasie próbki przesączono i wykonano oznaczenia fenolu.

Wptyw pH na proces adsorpcji

Badania wykonano w warunkach statycznych dla $\mathrm{pH}: 2,3,4,5,6,7,8,9$, $10,11,12$. Stężenie początkowe badanej wody to $\mathrm{C}_{0}=20 \mathrm{mg} \cdot \mathrm{dm}^{-3}$. Do $250 \mathrm{ml}$ adsorptywu dodano 2,5 g ASS, wstrząsano 3 godziny (stan równowagi adsorpcyjnej), a po sedymentacji wykonano oznaczenia fenolu w roztworze.

Adsorpcję fenolu wyznaczono z zależności:

$$
\mathrm{q}_{\mathrm{r}}=\mathrm{V} \cdot\left(\mathrm{C}_{0}-\mathrm{C}_{\mathrm{r}}\right) / \mathrm{m}, \quad\left(\mathrm{mg} \cdot \mathrm{g}^{-1}\right)
$$

gdzie: V - objętość adsorptywu $\left(\mathrm{dm}^{3}\right)$,

$\mathrm{C}_{0} \mathrm{i}_{\mathrm{r}}-$ stężenie początkowe i równowagowe fenolu $\left(\mathrm{mg} \cdot \mathrm{dm}^{-3}\right)$,

$\mathrm{m}$ - masa złoża (g).

\section{Izotermy adsorpcji}

W stanie równowagi istnieje określony rozdział adsorbatu między adsorbatem i adsorbentem. Ten rozdział, w określonych warunkach prowadzenia procesu, opisują izotermy adsorpcji, przedstawiające zależność między ilością substancji zaadsorbowanej, a stężeniem równowagowym . Izotermy adsorpcji feno- 
lu wyznaczono dla warunków nieprzepływowych. Badania realizowano w naczyniach o zawartości $0,25 \mathrm{dm}^{3}$ adsorptywu i $2,5 \mathrm{~g}$ sorbentu, dla następujących stężeń fenolu $\mathrm{C}_{0}: 1,5,10,15,20,40,60,100,150,200 \mathrm{mg} \cdot \mathrm{dm}^{-3}$. Zawartość adsorbatu w stanie równowagi $\mathrm{q}_{\mathrm{r}}$, po 3 godzinach wstrząsania, obliczono ze wzoru (1).

$\mathrm{Na}$ podstawie otrzymanych wyników sporządzono izotermy Freundlicha i Langmuira. Izotermy adsorpcji fenolu na ASS wyznaczono dla temp. $20^{\circ} \mathrm{C}$ i przy pH 6,5 .

\section{Adsorpcja fenolu w warunkach przeptywowych (filtracja)}

Warunki dynamiczne realizowane były metodą filtracji kolumnowej (DN $35 \mathrm{~mm}$ ). Były realizowane $\mathrm{w}$ trzech seriach: $\mathrm{z}$ czasem retencji $\mathrm{t}_{\mathrm{r} 1}=1,6 \mathrm{~min}$, $\mathrm{t}_{\mathrm{r} 2}=5 \mathrm{~min}$ i $\mathrm{t}_{\mathrm{r} 3}=10 \mathrm{~min}$. Masa adsorbentu $\mathrm{w}$ kolumnie wynosiła odpowiednio 58 g i 170 g i 340 g. Filtracja prowadzona była w kierunku z góry do dołu $\mathrm{z}$ prędkością $2 \mathrm{~m} \cdot \mathrm{h}^{-1}$. Przepuszczano przez złoże roztwór fenolu o stężeniu początkowym $\mathrm{C}_{0}=20 \mathrm{mg} \cdot \mathrm{dm}^{-3}$. Filtracja trwała do momentu wyczerpania złoża.

Wyznaczaną pojemność sorpcyjną w punkcie wyczerpania złoża wyznaczano z zależności:

$$
\mathrm{P}=\mathrm{V} \cdot\left(\mathrm{C}_{0}-\mathrm{C}_{\mathrm{k}}\right) / \mathrm{m}
$$

gdzie: $\mathrm{P}$ - pojemność sorpcyjna złoża $\left(\mathrm{mg} \cdot \mathrm{g}^{-1}\right)$,

$\mathrm{V}$ - objętość uzdatnionej wody $\left(\mathrm{dm}^{3}\right)$,

$\mathrm{C}_{0}$ - stężenie początkowe adsorbatu $\left(\mathrm{mg} \cdot \mathrm{dm}^{-3}\right)$,

$\mathrm{C}_{\mathrm{k}}-$ stężenie fenolu w wycieku $\left(\mathrm{mg} \cdot \mathrm{dm}^{-3}\right)$,

$\mathrm{m}$ - masa złoża $(\mathrm{g})$.

\section{Wyniki badań i ich omówienie}

\subsection{Kinetyka adsorpcji}

Nasycenie adsorbatem każdej cząstki adsorbentu zależy od szybkości dyfuzji cząsteczek pochłanianych do wnętrza granulki. Kinetyka adsorpcji stwarza możliwość określenia zależności szybkości adsorpcji od właściwości adsorbentu i od warunków samego procesu adsorpcji. Osiągany stan równowagi adsorpcyjnej wyraża się zależnością opisującą zmianę ilości zaadsorbowanej substancji w czasie.

Zależność stężenia końcowego adsorbatu dla ASS od czasu adsorpcji opisuje rysunek 1. 


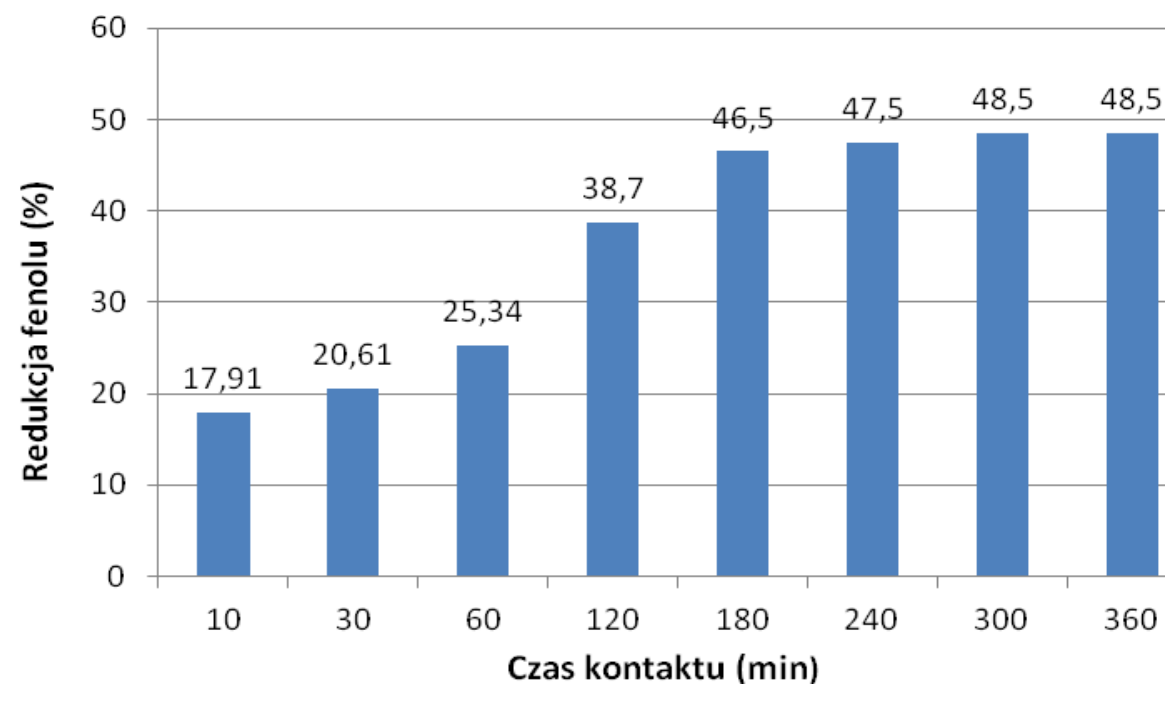

Rys.1. Wpływ czasu kontaktu na usunięcie fenolu (na ASS), przy pH 6,5

Fig. 1. Effect of contact time for the removal of phenol (onto ASS) at $\mathrm{pH} 6.5$

Z uzyskanych wyników badań można wnioskować, że czas adsorpcji miał istotny wpływ na skuteczność usuwania fenolu. Znacząca redukcja nastąpiła po 120 minutach, czas równowagi adsorpcyjnej został osiągnięty po 180 minutach. Potem nastąpiła stabilizacja i do dalszych badań (wyznaczenie izoterm) przyjęto czas retencji $3 \mathrm{~h}$.

\subsection{Wpływ pH}

Wpływ odczynu roztworu na adsorpcje fenolu przedstawiono na rys. 2. Dla adsorbentu ASS adsorpcja utrzymywała się na podobnym poziomie od $2-7 \mathrm{pH}$ i malała przy odczynie zasadowym.

Odczyn roztworu może mieć wpływ na proces adsorpcji z uwagi na zmianę właściwości powierzchniowych adsorbentu. Dla wielu ciał stałych, jonami potencjałotwórczymi sa jony $\mathrm{H}^{+}$i $\mathrm{OH}^{-}, \mathrm{z}$ czego wynika, że na potencjał powierzchni można wpływać przez zmianę pH roztworu, w którym znajduje się dane ciało stale. W badanym przypadku nie zauważono silnej adsorpcji jonów potencjałotwórczych na powierzchni ASS, wiec prawdopodobnie ładunek warstwy adsorpcyjnej zmienił swojego znaku (w zakresie odczynu obojętnego ASS, jako glinokrzemian posiada ładunek powierzchniowy ujemny). Wyraźnie widoczna była zależność, że przy wyższych pH zdysocjowane (ujemne) cząstki fenolu ( $\mathrm{pK}_{\mathrm{a}}$ stała dysocjacji - ok. 9,8 pH) zmniejszały swoje powinowactwo do ASS, dlatego w zakresie wyższych $\mathrm{pH}$ adsorpcja fenolu była zdecydowanie mniejsza. 


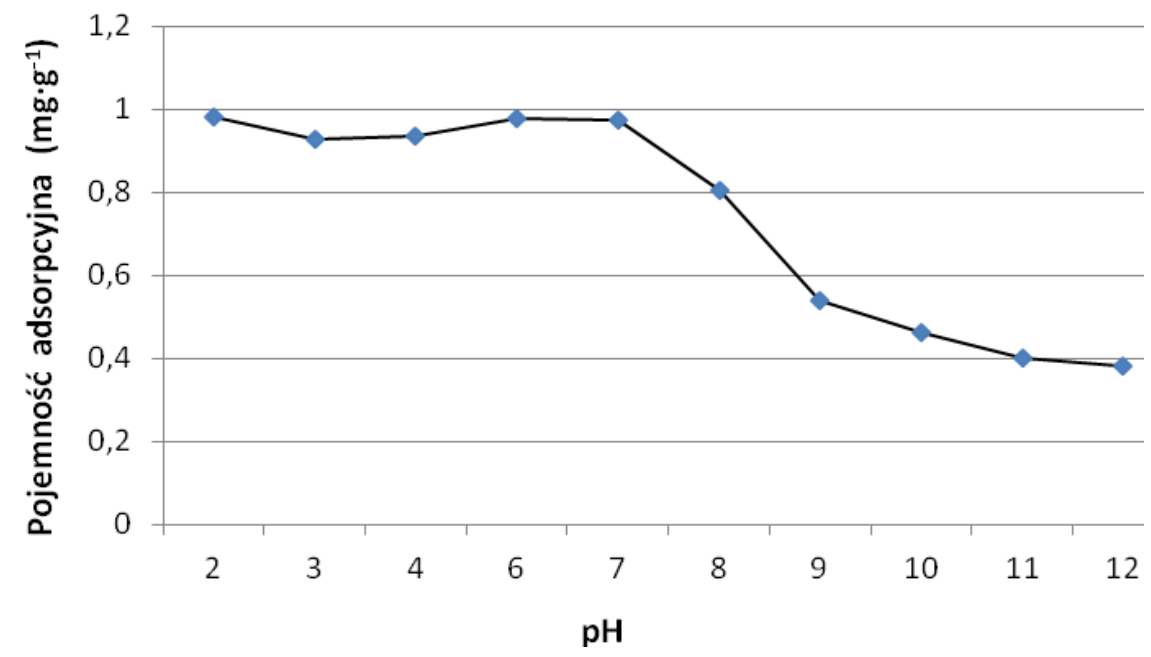

Rys. 2. Wpływ pH na adsorpcję fenolu

Fig. 2. Effect of $\mathrm{pH}$ on the phenol adsorption

Dla testowanego adsorbentu wzrost pojemności adsorpcyjnej dla $\mathrm{pH}$ poniżej 7 nie był na tyle znaczący, aby wprowadzać korektę odczynu wody. Dalsze badania prowadzono przy $\mathrm{pH}=6,5$.

\subsection{Izotermy adsorpcji}

Adsorpcyjne właściwości diatomitów opisano w oparciu o modele Freundlicha i Langmuira[12]:

- Równania Freundlicha:

$x / m=K \cdot C^{1 / n}$

gdzie : $x$ - ilość substancji zaadsorbowanej [mg]

$m$ - masa adsorbenta $[\mathrm{g}]$

$C$ - stężenie równowagowe $\left[\mathrm{mg} \cdot \mathrm{dm}^{-3}\right]$

$K, n$ - stałe izotermy

Wartości stałych $\mathrm{K}$ i n wyznaczyć można z logarytmicznej postaci równania, która przedstawia się następująco:

$\log \frac{x}{m}=\log K+\frac{1}{n} \log C$ 
- $\quad$ Równanie Langmuira:

$$
\frac{x}{m}=\frac{a \cdot b \cdot C}{1+b \cdot C}
$$

gdzie: $\mathrm{x} / \mathrm{m}$ - pojemność adsorpcyjna

$\mathrm{a}, \mathrm{b}$ - stałe równania Langmuira

$\mathrm{C}$ - końcowe stężenie adsorbatu w roztworze (w stanie równowagi).

Przekształcone równanie Langmuira pozwala na wyznaczenie stałych izotermy a i b:

$$
\frac{C}{x / m}=\frac{1}{a \cdot b}+\frac{1}{a} \cdot C
$$

Izotermy adsorpcji fenolu dla testowanego adsorbentu przedstawia rys. 3 . Przebieg izoterm (wyznaczonych w warunkach statycznych) wskazuje, adsorpcję fenolu na ASS znacznie lepiej opisuje izoterma Freudlicha.

Stałe izoterm i stopień dopasowania zamieszczone są w tabeli 2.

Współczynnik determinacji $\mathrm{R}^{2}$ dla izotermy Freudlicha był dużo wyższy niż dla izotermy Langmuira, co świadczy o bardzo dobrym dopasowaniu do wartości eksperymentalnych i możliwości obliczania na jego podstawie, pojemności adsorpcyjnych ASS w odniesieniu do fenolu, dla założonych stężeń równowagowych.

Tab. 2. Stałe izoterm dla adsorpcji fenolu na ASS

Tab. 2. Constant for adsorption isotherms of phenol onto ASS

\begin{tabular}{|c|c|c|}
\hline \multicolumn{2}{|c|}{ Stale dla izotermy Freundlicha } & \multirow{2}{*}{ Wspólczynnik determinacji $\mathbf{R}^{\mathbf{2}}$} \\
\hline $\mathbf{K}$ & $\mathbf{n}$ & 0,9871 \\
\hline 0,096 & 1,15 & \multirow{2}{*}{ Wspólczynnik determinacji $\mathbf{R}^{2}$} \\
\hline Stałe dla izotermy Langmuira & $\mathbf{b}$ & 0,7848 \\
\hline $\mathbf{a}$ & 0,007 & \\
\hline 12,27 & &
\end{tabular}


a)

b)
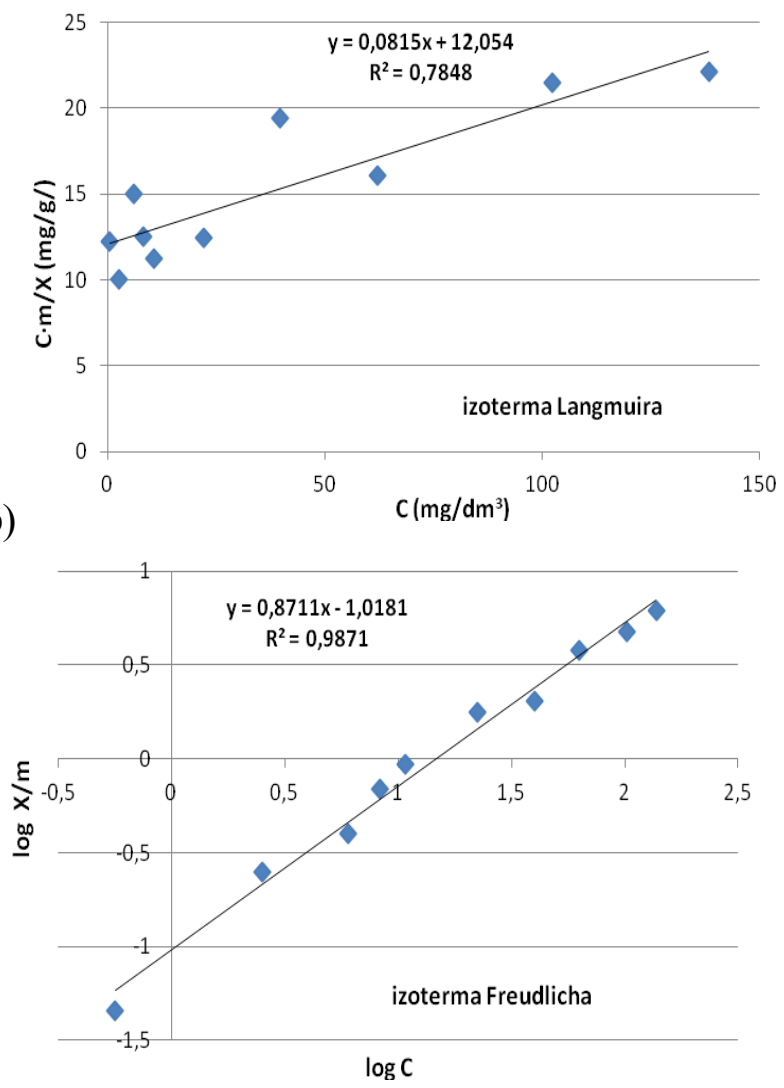

Rys. 3. Izotermy adsorpcji fenolu na ASS ( $\mathrm{pH}=6,5$, temp. $20^{\circ} \mathrm{C}$ ), a) Feundlicha, b) Langmuira Fig. 3. Adsorption isotherms of phenol onto ASS $\left(\mathrm{pH}=6.5\right.$, temp. $\left.20^{\circ} \mathrm{C}\right)$, a) Feundlicha, b) Langmuira

\subsection{Dynamika adsorpcji fenolu na ASS}

Przebieg filtracji przy różnych czasach retencji, do punktu wyczerpania złóż obrazuje rysunek 4.

Adsorpcja fenolu na testowanych złożach była zróżnicowana. Słabo usuwany był fenol na w kolumnie filtracyjnej z czasem kontaktu $\operatorname{tr}=1,6$ min. Filtracja była krótka i nawet w początkowej fazie pracy złoża nie uzyskano niskiego stężenia fenolu w wycieku (około $18 \mathrm{mg} \cdot \mathrm{dm}^{-3}$ ). Pojemność adsorpcyjna w punkcie wyczerpania złoża była bardzo mała $\mathrm{i}$ wyniosła $\mathrm{P}=0,23 \mathrm{mg} \cdot \mathrm{g}^{-1}$. Najefektywniej pracowało złoże $\mathrm{z}$ najdłuższym czasem retencji tr $=10$ minut. Cykl filtracyjny trwał znacznie dłużej (pięcioktotnie), a związki fenolu w początkowej fazie pracy kolumny usuwane były do wartości poniżej $0,5 \mathrm{mg} \cdot \mathrm{dm}^{-3}$. W punkcie wyczerpania złoża, przyjętego po przefiltrowaniu 50 litrów adsorptywu, uzyskano po- 
jemność adsorpcyjną dziesięciokrotnie większą $\left(P=2,45 \mathrm{mg} \cdot \mathrm{g}^{-1}\right)$. Niewiele mniejszą pojemność adsorpcyjną otrzymano $\mathrm{w}$ przypadku filtracji z czasem retencji tr $=5$ minut, wynoszącą $\mathrm{P}=2,1 \mathrm{mg} \cdot \mathrm{g}^{-1}$, jednakże stężenie fenolu $\mathrm{w}$ wycieku przez dłuższy czas filtracji utrzymywało się na poziomie $4-5 \mathrm{mg} \cdot \mathrm{dm}^{-3}$.

Po przeprowadzonych filtracjach wyraźnie widać, że czas retencji ma decydujące znaczenie i poprawia skuteczność usuwania fenolu.

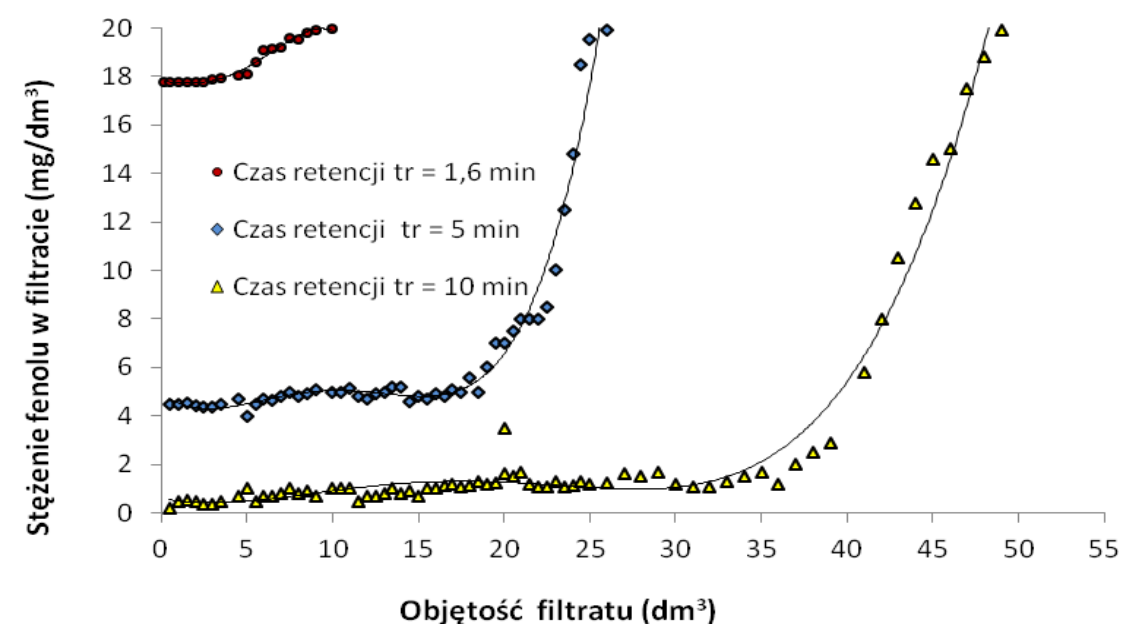

Rys. 4. Izoplany usuwania fenolu na złożu ASS, $\mathrm{C}_{0}=20 \mathrm{mg} \cdot \mathrm{dm}^{-3}$

Fig. 4. Izoplanes removal of phenol onto the ASS bed, $\mathrm{C}_{0}=20 \mathrm{mg} \cdot \mathrm{dm}^{-3}$

\section{Podsumowanie}

Przeprowadzony proces adsorpcji na naturalnym attapulgicie (ASS) (handlowa nazwa Abso'Net Superior Special) wykazał przydatność tego minerału do usuwania fenolu z roztworów wodnych.

Na stopień redukcji fenolu miał wpływ odczyn roztworu. Najkorzystniejszy był poniżej $7 \mathrm{pH}$. Adsorpcja fenolu malała wraz ze wzrostem alkaliczności roztworu.

Równowagę adsorpcyjną można analizować w oparciu o model Freundlicha, którego dopasowanie do warunków eksperymentalnych, w odniesieniu do ASS, było bardzo dobre, zaś uzyskane stałe $\mathrm{K}$ i n porównywalne $\mathrm{z}$ wieloma innymi adsorbentami (bentonit, węgle aktywne, diatomit i inne [3, 8, 17].

Usuwanie fenolu w warunkach dynamicznych, w procesie filtracji na złożu $\mathrm{z}$ czasem kontaktu $\mathrm{t}=10$ minut, okazało się dość skuteczne. Badania wykazały, że adsorbent o granulacji 0,6 - 1,3 mm zastosowany jako złoże adsorpcyjne mógłby stanowić alternatywę dla skutecznego podczyszczania roztworów zawierających fenol o stężeniach nie przekraczających $20 \mathrm{mg} \cdot \mathrm{dm}^{-3}$. 


\section{Literatura}

[1] An F., Gao B., Feng X., Adsorption mechanism and property of novel composite material PMAA/ $\mathrm{SiO}_{2}$ towards phenol, Chemical Engineering Jurnal, 2009, 153 (1-3), 108-113.

[2] Anielak A.M., Chemiczne I Fizykochemiczne Oczyszczanie Ścieków, PWN, Warszawa 2000.

[3] Banat F. A., Al-Bashir B., Al-Asheh S., Hayajneh O., Adsorption of phenol by bentonite, Environmental Pollution, 2000, 107 (3), 391-398.

[4] Bielicka- Daszkiewicz K.: Usuwanie fenolu z wód ściekowych przez utlenianie., Przemysł chemiczny nr 87(1), 2008, 24-32.

[5] Campbell M., Ph.D, Staff Toxicologist, Reproductive and Cancer Hazard Assessment: Section Evidence on the developmental and reproductive toxicity of phenol, California, 2003.

[6] Dąbrowski A., Adsorption from theory to practice. Advances in Colloid and Interface Science, nr 93 (2001), 135-224.

[7] Dąbrowski A. i inni: Adsorpcja fenoli na węglu aktywnym., Wiadomości chemiczne t. 59, nr 7-8, 2005, 639- 694.

[8] Dursun G., Handan Çiçek H., Dursun A.Y.. Adsorption of phenol from aqueous solution by using carbonised beet pulp, Journal of Hazardous Materials, 2005, 125, (1-3), 175-182.

[9] Federal Office for the Environment (FOEN), Micropollutants in municipal wastewater. Processes for advanced removal in wastewater treatment plants , Bern, 2012.

[10] Kaleta J., Fenole w środowisku wodnym, Ekologia i Technika, nr 1(73), Bydgoszcz, 2005, 3-11.

[11] Kaleta J., Proces sorpcji w usuwaniu wybranych zanieczyszczeń organicznych z roztworów wodnych, Z.N.P.Rz., nr 241, z. 43, Rzeszów 2007, 17-30.

[12] Khraisheh M.A.M., Al-Degs Y. S., Mcminn W. A.M., Remediation of wastewater containing heavy metals using raw and modified diatomite, Chemical Engineering Journal 99, 177-184, 2004.

[13] Liu Q-S., Zheng T., Wang P., Jiang J.P., Li N., Adsorption isotherm, kinetic and mechanism studies of some substituted phenols on activated carbon fibers, Chemical Engineering Journal, 2010, 157, (2-3), 348-356.

[14] Magrel L., Uzdatnianie wody i oczyszczanie ścieków. Urządzenia, procesy, metody., Wyd. Ekonomia i Środowisko, Białystok, 2000.

[15] Mc Murry J., Chemia Organiczna, PWN, 2000.

[16] Mohd Din A.T., Hameed B.H., Ahmad A.L., Batch adsorption of phenol onto physiochemical-activated coconut shell, Journal of Hazardous Materials, 2009, 161 (2-3), 1522-1529.

[17] Puszkarewicz A., Analiza adsorpcji fenolu na surowych i modyfikowanych diatomitach karpackich, Chemia, Dydaktyka, Ekologia, Metrologia 2010, R. 15, nr 2, 189.

[18] Rybiński, P., Janowska G., Palność oraz inne właściwości materiałów i nanomateriałów elastomerowych. Cz. II. Nanokompozyty elastomerowe z attapulgitem, nanokrzemionką, nanowłóknami, nanorurkami węglowymi, Polimery 2013, nr 7-8, 533. 
[19] Subramanyam B., Das A., Study of the adsorption of phenol by two soils based on kinetic and isotherm modeling analyses, Desalination, 2009, 249 (3), 914-921.

[20] Szperliński Z.: Chemia w ochronie i inżynierii środowiska. Część I., Oficyna Wydawnicza Politechniki Warszawskiej, Warszawa, 2002, 335- 367.

[21] Zhang J.: Phenol removal from water with potassium permanganate modified granular activated carbon, Journal of Environmental Protection, 4(2013), 411 - 417.

\section{REMOVAL OF PHENOL IN ADSORPTION PROCESS}

\section{S u m m a r y}

The natural mineral adsorbent (raw attapulgite - Abso'Net Superior Special (ASS)) was used for removing phenol compounds from water solutions. The adsorptive properties of attapulgite have been determined using static and dynamic methods. The tests were performed on/with a model solution of phenol at initial concentration of $\mathrm{C}_{0}=20 \mathrm{~g} \cdot \mathrm{dm}^{-3}$, at the temperature of $20^{\circ} \mathrm{C}$. For tested attapulgite grades the adsorption processes was described adequately by Froundlich adsorption isotherms. The tests showed that phenol adsorption proceeded slightly better in neutral and acid reaction. Based on the research, it was found that the adsorption time had a considerable impact on the efficiency of removing phenol. Time adsorption equilibrium occurred after $180 \mathrm{~min}-$ utes. In the flow conditions, the most effectively worked the bed with the longest retention times $\operatorname{tr}=10 \mathrm{~min}$. The compounds of the phenol in the initial phase of operation of the column were removed to less than $0.5 \mathrm{mg} \cdot \mathrm{dm}^{-3}$. At the point of exhaustion deposits obtained adsorption capacity $\mathrm{P}=2.45 \mathrm{mg} \cdot \mathrm{g}^{-1}$. Removal of phenol by filtration on a bed of attapulgite - Abso'Net Superior Special (ASS) proved effective. Studies have shown that the adsorbent with particle size $0.6-1.3 \mathrm{~mm}$ used as an adsorbent bed could be an alternative to the effective pretreatment solutions containing phenol of concentration not exceeding $20 \mathrm{mg} \cdot \mathrm{dm}^{-3}$.

Keywords: phenol, adsorption, filtration, attapulgite

Przestano do redakcji: $30.05 .2015 r$.

Przyjęto do druku:30.10.2015r.

DOI: $10.7862 / \mathrm{rb} .2015 .160$ 